\title{
Ruchy separatystyczne i dezintegracyjne przełomu XX i XXI wieku w Europie
}

\begin{abstract}
Streszczenie: Istnienie w Europie ruchów separatystycznych i dezintegracyjnych, punktów zapalnych oraz konfliktów zbrojnych przekonuje, że nasz kontynent nie jest miejscem spokojnym ani bezpiecznym. Nawet, jeżeli uważamy go za najbezpieczniejszy na naszym globie. Po 1989 roku zapanowała w Europie demokracja, w latach 1999-2013 do zachodnich struktur obronnych (NATO) i gospodarczych (UE) włączono kraje Europy Środkowo-Wschodniej, wiązano z tym wielkie nadzieje na przyszłość. W drugiej dekadzie XXI wieku w Europie pojawiły się zupełnie inne tendencje. W prawie wszystkich krajach europejskich nasiliły się ruchy separatystyczne i populistyczne. W artykule postawiono następujące pytania badawcze:

1. Jakie jest źródło ruchów separatystyczno-populistycznych?

2. Co leży u podstaw odrodzenia nacjonalizmu w państwach europejskich?

3. Dlaczego polityka autonomii regionów nie skutkuje?

4. Co może być skutkiem rozbicia etnicznego kolejnych państw w Europie?

Posłużono się metodą komparatystyczną oraz analizą systemową. Rozpoznając badany problem, autor doszedł do następujących wniosków:

1. W Europie występują problemy, które prowadziły i mogą doprowadzić do wojen.

2. Żadne państwo nie może się czuć bezpieczne, nawet, jeśli samo jest stabilne i demokratyczne.

3. Ekstremistyczne ugrupowania i ruchy polityczne mogą zdestabilizować kontynent.

4. Jednym antidotum w uspakajaniu konfliktów oraz eliminowania sytuacji separatystycznych jest ugruntowana i stabilna demokracja.

5. Polityka europejska (UE) powinna w tej kwestii być jednoznaczna i stabilna.
\end{abstract}

Słowa kluczowe: ruchy separatystyczne, polityka etniczna, tożsamość, dezintegracja

$\mathbf{A}^{\mathrm{n}}$ nalizując społeczeństwa europejskie na przełomie XX i XXI wieku można zauważyć pewną dychotomię. Pod koniec ubiegłego wieku świat, w tym Europa, stawała się globalna, próbowano stworzyć system polityczny bez granic dążący do demokracji i integracji (Piwnicki, 2016, s. 328-333).

Było to swoistym marzeniem państw naszego kontynentu po kataklizmie II wojny światowej - rozwój oparty na współpracy i poszanowania pokoju. Nie było to udziałem wszystkich narodów europejskich, gdyż część z nich znalazła się za żelazną kurtyną okresu zimnej wojny do 1989 roku. Ludność Europy pamiętała dramatyczne czasy wojny. Między 1939 i końcem 1945 roku, co najmniej 60 milionów Europejczyków - nie licząc żołnierzy i jeńców - straciło swoje domostwa i zmieniło miejsce zamieszkania na skutek zniszczeń, bombardowań, wysiedleń, ucieczek i zmian terytorialnych między państwami, piętno tej przymusowej migracji naznaczyło powojenne pokolenia. Europa jeszcze podzielona politycznie doszła wspólnie do wniosku, że rękojmią jej rozwoju i przyszłości musi być pokojowa koegzystencja. Takie było założe- 
nie Konferencji Bezpieczeństwa i Współpracy w Europie oraz jej Aktu Końcowego" Chodziło w nim, aby konfrontacja dwu ustrojów, która odbywa się na jej obszarze, poddana została regułom minimalizującym możliwość konfliktu i maksymalizującym możliwości współpracy. Ustalono, a następnie rozwinięto 10 zasad prawno-politycznych, które uczestniczące państwa uznały za podstawowe dla prawidłowego rozwoju ich wzajemnych stosunków:

1) równość suwerenna i poszanowanie niezbywalnych praw z suwerenności wynikających;

2) nieuciekanie się do stosowania siły lub groźby jej użycia;

3) nienaruszalność granic;

4) integralność terytorialna państw;

5) pokojowe rozwiązywanie sporów;

6) nieinterwencja w sprawy wewnętrzne państw;

7) poszanowanie praw człowieka i podstawowych wolności, w tym wolności myśli, sumienia, religii i przekonań;

8) równość praw narodów i prawo narodów do samostanowienia;

9) współpraca między państwami;

10. wykonywanie w dobrej wierze zobowiązań, przyjętych zgodnie z prawem międzynarodowym.

Ponadto zobowiązano się do wzajemnej wymiany gospodarczej i kulturalnej (Dobraczyński, Stefanowicz, 1979, s. 100). Po 2015 roku zarysował się podział w Unii Europejskiej (28 krajów członkowskich) na prounijne i antyunijne (Węgry, Polska, Czechy, Słowacja). Na tym tle narasta tendencja podziału Unii na te o ,twardym jądrze” (strefa euro i peryferyjne państwa, które nie chcą zacieśniać Unii i przyjmować jej waluty!). Bardzo groźnym symptomem jest odrodzenie się w niektórych państwach ruchów neonazistowskich i skrajnej prawicy, m.in. w Polsce $(\mathrm{ONR})^{2}$, Węgrzech, neonaziści w Niemczech Wschodnich. Nasilające się trendy mogą zdecydować o przyszłym rozwoju Wspólnoty Europejskiej (Piwnicki, 2017, s. 25-49).

${ }^{1} 1$ sierpnia 1975 roku w Helsinkach doszło do podpisania Aktu Końcowego Konferencji Bezpieczeństwa i Współpracy w Europie (KBWE). Od tego czasu rozpoczął się rozwój procesu KBWE.

2 W latach 30. XX wieku sympatia narodowców w Polsce przesuwała się od fascynacji faszyzmem włoskim do niemieckiej wersji narodowego socjalizmu, który młodzież pociągał programem rozwiązania tzw. kwestii żydowskiej. Hasło „Polska dla Polaków”, padało na podatny grunt. Na tle ksenofobicznym dochodziło w wielu miastach Polski do walk ulicznych. Z tych powodów OWP (Obóz Wielkiej Polski) został w 1933 roku rozwiązany przez marszałka Józefa Piłsudzkiego. W chwili jego delegalizacji liczył około 250 tys. członków. Por. B. Grott, Nacjonalizm chrześcijański. Narodowokatolicka formacja ideowa w II Rzeczypospolitej na tle porównawczym, Krzesłowice 1999, s. 62. Po rozwiązaniu, większość jego członków przeszła w szeregi Stronnictwa Narodowego, aby następnie zasilić Obóz Narodowo-Radykalny. Po 1934 roku duży odłam Wszechpolaków przesunął swoją działalność do ONR, 3 maja 1934 roku w Warszawie miał miejsce pochód - manifestacja ONR. Umundurowane kolumny młodych ludzi niosły dwa wielkie miecze Chrobrego: „,na ramionach mieli zielone opaski z symbolem ONR - ręką trzymającą miecz - wspominał swoją fascynację ONR-em późniejszy działacz „Falangi” - Zygmunt Przetakiewicz. 10 lipca 1934 roku ONR został rozwiązany przez władze państwowe, jednak powstał trwały ślad w postaci nacjonalizmu, antysemityzmu i stereotypu „Polak - Katolik”. Por. D. Waniek, Ruch narodowy w Polsce wczoraj i dziś, ideologia, organizacja, praktyka działania, Warszawa 2014, s. 55. 


\title{
Współczesne ruchy separatystyczne i dezintegracyjne w Europie
}

\author{
Niemcy - podwójna tożsamość
}

Polityka Unii Europejskiej w pewnym stopniu spowodowała uaktywnienie się ruchów dezintegracyjnych. Wspomaganie regionów sprzyjało aktywności ruchów separatystycznych. Jedne zadowalały się przyznaniem ich małej ojczyźnie odrębnych praw, inne chciały autonomii albo żądały niepodległości. Ruchy separatystyczne pojawiły się w Niemczech i we Włoszech, co nie dziwi, gdyż obywatele obu tych państw mają historycznie uwarunkowane poczucie podwójnej tożsamości. Mieszkańcy landów w RFN czują się nie tylko Niemcami, ale też Hamburczykami, Westfalczykami, Sasami itd. Najsilniej poczucie odrębności manifestowali Bawarczycy, którzy na granicy z sąsiednimi landami i państwami umieścili bilboardy informujące o tym, że właśnie wjechało się do Bawarii. Jednak podwójna tożsamość nie grozi dezintegracją ani RFN, ani Unii Europejskiej.

\section{Włochy - podwójna tożsamość}

Podwójna tożsamość mieszkańców Włoch oraz znaczne różnice w poziomie rozwoju cywilizacyjnego regionów prowadziły do manifestacji ich prawa do autonomii, a nawet niepodległości. W latach 90. hasła niepodległościowe głosiła Liga Północna, kierowana przez Umberto Bossiego, która uzyskała spore wpływy w zamożnej Lombardii, Piemoncie i Wenecji. Na początku lat 90 . forsowała nawet pomysł stworzenia nowego państwa o nazwie Padonia, argumentując, że pieniądze zarobione w Turynie czy Mediolanie powinny być wydawane na miejscu, a nie transferowane do biednych regionów: Neapolu, Kalabrii, Sycylii. W 1989 roku PKB wytworzony w Lombardii wynosił 132\% średniej krajowej, a w Kalabrii - 56\%. Uzasadnieniem dla powołania nowego państwa miało być istnienie odrębnego narodu Lombardczyków, o korzeniach jakoby celtyckich. W 1996 roku w Wenecji Bossi ogłosił powstanie Padonii, zaprezentował jej biało-zieloną flagę oraz projekt konstytucji wzorowanej na amerykańskiej, a na ulicach pojawili się zwolennicy nowego państwa w koszulkach z napisem: „Padonia to nie Włochy”. Co prawda w istocie ten pomysł odrębnego państwa upadł, problemy pozostały i Liga Północna dalej cieszy się na północy Włoch poparciem. Ujawniali się też zwolennicy Rzeczypospolitej Weneckiej, wywieszający na dzwonnicy na placu św. Marka jej flagę z lwem, dalej zwolennicy Państwa Kościelnego w Rzymie, a także niezależnej Sycylii i Sardynii.

Francja - ruchy autonomiczne

Mimo niezwykle konsekwentnej polityki centralistycznej, we Francji wciąż zaznaczają swą obecność odrębności regionalne. Manifestowali je mieszkańcy Langwedocji - nawiązujący do tradycji średniowiecznych katarów, Alzacji - podkreślający germań- 
skie korzenie, Bretanii - odwołujący się do kultury celtyckiej. Jednak świadomość silnych więzi kulturowych i ekonomicznych z resztą Francji powodowała, że mieszkańcy tych krain zadowoliliby się autonomią. O autonomii rządowe władze Francji w ogóle nie chciały rozmawiać. W tej sytuacji liderzy ruchów autonomicznych Langwedocji, Alzacji i Bretanii, świadomi wąskiego poparcia społecznego, nie byli zdolni do zdecydowanej walki o urzeczywistnienie programowych celów. Odrębny problem stanowią Korsykanie, używający własnego, bliskiego włoskiemu języka, marzący, jeśli nie o niepodległości, to o rozległej autonomii, gwarantującej im spore subwencje rządowe i ulgi podatkowe. Większość mieszkańców Korsyki pragnie to uzyskać na drodze legalnej. Natomiast separatyści na drodze terroru, organizując zamachy m.in. na francuskich urzędników, policjantów i korsykańskich „kolaborantów”. Terrorystyczne metody ograniczają im poparcie. Dlatego większość mieszkańców wyspy boi się zwycięstwa separatystów, bo byłoby to zapowiedzią rządów bezprawia i silnych wpływów mafii korsykańskiej.

\section{Wielka Brytania - ruchy separatystyczne}

Separatyzm stale był obecny w Wielkiej Brytanii: Walii, Szkocji, Irlandii Północnej. Walijczycy i Szkoci oczekiwali od władz centralnych przyznania im niezależności w ramach Wielkiej Brytanii. Naprzeciw ich oczekiwaniom wyszedł rząd Blaira, który w 1997 roku na podstawie wyników referendów przyznał Szkocji i Walii rozległe uprawnienia. Dzięki temu dysponują własnym ciałem przedstawicielskim i rządem, a Szkocja też własnym systemem edukacji. Większość Szkotów uznała te ustępstwa za satysfakcjonujące, natomiast mniejszość głosująca na niepodległościową Szkocką Partię Narodową uważała, że skoro Szkocja posiada tak wielkie złoża ropy i gazu, to poradzi sobie bez Anglików i może utworzyć własne państwo. W 2007 roku separatyści szkoccy wygrali wybory, jednak nie udało im się doprowadzić do niepodległości. Takich sukcesów nie osiągnęli separatyści walijscy reprezentowani przez niepodległościową Partię Walii.

Najsilniejszy ruch separatystyczny w Wielkiej Brytanii był zlokalizowany w Irlandii Północnej/Ulsterze. Reprezentowali go katoliccy Irlandczycy, którzy stanowili ponad 40\% ogółu ludności. Żądali przyłączenia Irlandii Północnej do Republiki Irlandii. Dlatego mienili się republikanami, a legalnie działająca partia, która reprezentowała ich interesy, nazywała się Sinn Fein. Natomiast protestanci, zwani unionistami, sprzeciwiali się jakimkolwiek ustępstwom na rzecz katolików, opowiadając się za silnym związkiem z Londynem. Obie niechętne sobie wspólnoty, katolicka i protestancka, mieszkały w odrębnych dzielnicach miast. I jedni, i drudzy dysponowali uzbrojonymi bojówkami. Przez dziesięciolecia Irlandia Północna/Ulster była polem bitwy, największym w Europie Zachodniej. Irlandczycy skupieni w Irlandzkiej Armii Republikańskiej organizowali zamachy bombowe, na terenie Anglii. Partyzanci z IRA atakowali w angielskich pociągach i metrze, ostrzeliwali Londyn z rakiet i moździerzy, ginęli cywile. Margaret Thatcher nie rozmawiała z IRA.

Kolejni premierzy - John Major i Blair, postanowili zakończyć konflikt na drodze dyplomatycznej. Ich wysiłki wsparł prezydent USA Clinton. Również Irlandia szukała porozumienia, gdyż, zdawała sobie sprawę, że droga terroru niczego nie załatwi. 
31 sierpnia 1994 roku IRA ogłosiła zawieszenie broni, choć w praktyce go nie przestrzegała. Dopiero dzięki zdecydowanej presji premiera Blaira na unionistów i republikanów, w Wielki Piątek, 10 kwietnia 1998 roku podpisano porozumienie, które miało zakończyć krwawą wojnę. Od 1969 roku zginęło ponad 3,5 tys. osób, a 35 tys. zostało ranne. Na mocy porozumienia katolicy zostali zrównani w pełni pod względem prawnym z protestantami. Uzyskali możliwość piastowania najwyższych urzędów i zasiadania w nowym, wspólnym rządzie Irlandii Północnej, powstałym 29 listopada 1999 roku oraz w policji. Premierem Ulsteru został protestant, wicepremierem katolik. Utworzono również regionalny parlament ze stolicą w Belfaście. Porozumienie przewidywało, że jeśli w przyszłości wolą ludności będzie zjednoczenie z Irlandią, to Londyn nie będzie się temu sprzeciwiał. Irlandia w 1994 roku wykreśliła z konstytucji zapis, że Irlandia Północna stanowi część jej terytorium, a Wielka Brytania w późniejszym okresie usunęła zapis mówiący o wieczystym pozostawaniu Ulsteru w granicach Wielkiej Brytanii. Ostatnie zamachy przeprowadzono w dniach 7 i 9 marca 2009 roku (Kuczyński, 2001).

\section{Hiszpania - ruchy separatystyczne}

Silne ruchy separatystyczne istniały w Hiszpanii, zwłaszcza w Katalonii i Kraju Basków, a także w Galicji i Andaluzji. Katalończycy, uważający się za odrębny naród, od lat zabiegali o poszerzenie ich wolności autonomicznych. Na skutek tego sporo osiągnęli. Mają autonomiczny parlament i rząd, własną policję i system bezpieczeństwa, a język kataloński jest językiem urzędowym. Krok za krokiem zdają się podążać w kierunku niepodległości, choć nie wszyscy Katalończycy są przekonani, że będzie to dla nich korzystne. Katalonia stała się państwem w państwie (Chwalba, 2011, s. 231-234).

Aktualnie Katalonia ogłosiła 27 października 2017 roku niepodległość. Władze Hiszpanii zawiesily autonomię w celu zahamowania procesu separacji regionu od reszty kraju. Katalońskie ugrupowanie Secesjonistyczne - Zgromadzenie Narodowe Katalonii (ANC) wezwało urzędników, by stosowali „pokojowy opór” i nie słuchali poleceń rządu hiszpańskiego.

W tej kwestii Ruch Autonomii Śląska popiera kataloński separatyzm. Wydał oświadczenie, w którym skrytykował działania rządu Hiszpanii i poparł Katalończyków. RAŚ uznał, że sprawa Katalonii nie jest wewnętrzną sprawą Hiszpanii. Stanowisko idzie w tym kierunku, że gdyby nastąpił podobny konflikt na Śląsku, to według ugrupowania Gorzelika, nie Polska, a Unia powinna zająć się tą sprawą (Tomaszewski, 2018).

Hiszpańscy Baskowie, mimo posiadania szerokiej autonomii, w większości pragnęli niepodległości. O nią zabiegała zarówno umiarkowana chadecka Baskijska Partia Narodowa, jak i lewacka, radykalna partia Herri Batasuna, z którą współpracowała słynna terrorystyczna organizacja ETA. W 1995 roku jej żołnierze zorganizowali nieudany zamach na premiera Jose Marię Aznara, a w kolejnych latach króla Juana. W lipcu 1997 roku, po porwaniu i brutalnym zamordowaniu młodego hiszpańskiego policjanta, przeciwko działaniom ETA protestowało $6 \mathrm{mln}$ Hiszpanów. Z pewnością trudna sytuacja ekonomiczna w Kraju Basków - wynik upadku tradycyjnych działów gospodarki, przemysłu tekstylnego i metalurgicznego, sprzyjała radykalnym formacjom baskijskim. W latach 90. ETA osłabła z powodu trudności finansowych, zmęczenia Basków nieprzy- 
noszącym sukcesów politycznych terroryzmem oraz zdecydowania policji hiszpańskiej. Około 2000 roku ETA miała poparcie już tylko 15\% Basków, niemniej raz na jakiś czas przypominała o swoim istnieniu w znany już sposób. Znakiem zmęczenia radykalnymi programami niepodległościowymi było przejęcie 7 maja 2009 roku steru rządu Kraju Basków przez baskijskiego socjalistę Patxi Lópeza, zwolennika integralności terytorialnej Hiszpanii i zdecydowanego przeciwnika ETA (Stasiński, 2018). Była to sensacja największego kalibru, gdyż po raz pierwszy od 30 lat Baskijska Partia Narodowa nie utworzyła rządu (Chwalba, 2011, s. 234-235).

\section{Państwa - w ladzie międzynarodowym}

W stosunkach międzynarodowych państwa są traktowane, jako odrębne, jednolite całości, w każdym państwie narodowym istnieje szereg wewnętrznych podziałów i szczebli władzy. Przede wszystkim występuje podział według kryterium terytorialnego na władzę centralną i różne formy władzy regionalnej, stanowej i lokalnej. Podziały te kształtuje przede wszystkim struktura konstytucyjna państwa, która określa czy ma ono federalną, czy też unitarną formę. Każdy system rządów tworzy specyficzny terytorialny podział władzy, w ramach którego kształtują się relacje centrum peryferie. Wszystkie państwa współczesne podlegają także w różnym stopniu przeciwstawnym naciskom. $Z$ jednej strony czynniki ekonomiczne, międzynarodowe prowadzą do na pozór bezlitosnej centralizacji. Z drugiej strony, zwłaszcza pod koniec XX wieku, wraz ze wzrostem polityki etnicznej, regionalnej i lokalnej nasiliły się tendencje separatystyczne.

We wszystkich państwach współczesnych istnieje podział według kryterium terytorialnego na instytucje centralne i peryferyjne (regionalne, prowincjonalne lub lokalne). Natura tych podziałów jest jednak bardzo zróżnicowana, gdyż mogą one obejmować strukturę konstytucyjną, w obrębie której kształtują się relacje centrum-peryferie, dystrybucję funkcji i obowiązków między różne szczeble władzy, sposób mianowania i rekrutacji personelu, instrumenty polityczne, ekonomiczne, administracyjne i inne, które centrum może użyć, by kontrolować peryferie oraz niezależność, którą cieszą się władze lokalne. Oczywistym pozostaje jednak fakt, że nie można się obejść ani bez władz centralnych, ani lokalnych.

Bez władzy centralnej państwo nie byłoby w stanie funkcjonować na scenie międzynarodowej. Nie posiadałoby mechanizmu wchodzenia w sojusze strategiczne, negocjowania umów handlowych, reprezentacji na międzynarodowych szczytach i uzyskiwania członkostwa w organach ponadnarodowych. $Z$ tego względu władze centralne niezmiennie są odpowiedzialne za stosunki zewnętrzne państwa, co wyraża się w kontroli nad polityką zagraniczną, dyplomatyczną i obronną. Ponadto jakaś forma władzy centralnej jest potrzebna do mediacji pomiędzy organami władzy lokalnej w celu zapewnienia współpracy w obszarach będących przedmiotem wspólnego zainteresowania. W większości przypadków oznacza to, że władze centralne posiadają ogólną kontrolę nad życiem gospodarczym państwa i nadzorują takie obszary jak handel wewnętrzny, transport i komunikacja. Istnieją jednak ważne powody dalszego wzmacniania władz centralnych kosztem instytucji lokalnych (Jackson, 2011). 


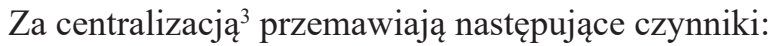

1) jedność narodowa - jedynie władze centralne przedstawiają interesy całości, a więc interesy narodu, a nie grup partykularnych, etnicznych czy regionalnych. Silne centrum jest gwarantem tego, że rząd realizuje interesy całej wspólnoty; słabe centrum prowadzi do rywalizacji i dysharmonii;

2) jednolitość - jedynie władze centralne mogą ustanawiać jednolite ustawodawstwo i świadczyć usługi publiczne, dzięki którym ludność łatwiej może przemieszczać się z jednej części kraju do drugiej. Funkcjonowanie różnych systemów podatkowych, prawnych, oświatowych oraz pomocy społecznej z dużym prawdopodobieństwem ograniczyłoby mobilność geograficzną;

3) równość - wadą decentralizacji jest to, że instytucje lokalne uzależnione są od zasobów dostępnych w ich miejscowości lub regionie. Jedynie władze centralne mogą korygować nierówności wynikające z faktu, że obszary o największych potrzebach socjalnych niezmiennie są tymi samymi, które mają najmniejsze możliwości uzyskania dochodu;

4) dobrobyt - rozwój gospodarczy i centralizacja niezmiennie chodzą ze sobą w parze. Jedynie władze centralne mogą, na przykład, zarządzać wspólną walutą, kontrolować politykę podatkową i wydatki, tak by zapewnić zrównoważony wzrost oraz, gdy to konieczne, zapewnić infrastrukturę w postaci dróg, kolei, lotnisk itd.

$\mathrm{Z}$ drugiej strony istnieją granice potrzebnej i pożądanej centralizacji. Wizja współczesnego państwa, które z centrum sprawuje całkowitą władzę nad dziesiątkami, a nawet setkami milionów obywateli jest po prostu absurdalna. Ogólnie mówiąc, obowiązki lokalnych instytucji mają charakter „miejscowy” w tym sensie, że przede wszystkim dotyczą potrzeb miejscowej ludności, na przykład w zakresie edukacji, zdrowia, pomocy społecznej i planowania. Znaczący jest jednak nacisk na przenoszenie innych obowiązków oraz uprawnień decyzyjnych z organów centralnych na lokalne.

Na rzecz decentralizacji ${ }^{4}$ przemawiają następujące czynniki:

1) uczestnictwo - władze lokalne lub regionalne z pewnością są bardziej efektywne niż centralne w dawaniu obywatelom możliwości uczestnictwa w życiu politycznym ich wspólnoty. Poszerzenie zakresu uczestnictwa politycznego przyczynia się do stworzenia lepiej wykształconego i poinformowanego społeczeństwa;

2) zdolność reakcji - lokalne instytucje są zazwyczaj bliżej ludzi i są bardziej wrażliwe na ich potrzeby. Przyczynia się to do umacniania odpowiedzialności przed wyborcami, jak i zapewnia, że rząd reaguje nie tylko na ogólne interesy społeczeństwa, ale także na określone potrzeby poszczególnych wspólnot;

3) legitymizacja - fizyczna odległość od rządu ma wpływ na akceptowalność czy też słuszność jego decyzji. Decyzje podejmowane na szczeblu lokalnym z większym prawdopodobieństwem zostaną zrozumiane, a zatem uznane za uprawnione. Władze centralne, przeciwnie, mogą być postrzegane, jako odległe zarówno geograficznie, jak i politycznie;

4) wolność - ponieważ władza korumpuje, centralizacja grozi przekształceniem rządu w tyranię przeciw jednostkom. Decentralizacja ochrania wolność poprzez rozpro-

${ }^{3}$ Centralizacja - koncepcja władzy politycznej na szczeblu centralnym państwa.

${ }^{4}$ Decentralizacja - rozszerzeni autonomii lokalnej w wyniku przekazania kompetencji i obowiązków przez organy centralne. 
szenie władzy tworząc w rezultacie sieć mechanizmów kontroli i równowagi. Organy władzy lokalnej kontrolują władze centralne i siebie nawzajem (Heywood, 2006, s. 199-201).

\section{Polityka etniczna}

Polityczna decentralizacja, a w skrajnych przypadkach, zjawisko rozpadu państw, jest w coraz większym stopniu wspierana przez nowy styl uprawiania polityki - politykę lojalności etnicznej i tożsamości regionalnej. W pewnej mierze pojawienie się polityki etnicznej pod koniec XX wieku odpowiadało powstaniu polityki nacjonalistycznej w XIX wieku i może mieć podobne, daleko idące konsekwencje. Podczas gdy nacjonalizm zapoczątkował okres budowania narodów oraz rozpadu wielonarodowych imperiów, polityka etniczna może postawić pod znakiem zapytania przetrwanie narodu w dłuższej perspektywie. Innymi słowy, nacjonalizm może zostać zastąpiony przez wielokulturowość. Jakie są przyczyny powstania tego nowego stylu uprawiania polityki i jaki jest jego charakter polityczny?

Rosnąca rola świadomości etnicznej na Zachodzie jest fenomenem właściwym okresowi po II wojnie światowej, a właściwie jej korzenie sięgają lat 60 . Ponowny wzrost znaczenia etniczności w polityce był zaskoczeniem dla większości komentatorów, jego powodem było rozpowszechnione przekonanie, że nowoczesność doprowadzi do zacierania się różnic etnicznych, gdyż rozprzestrzenianie się wartości liberalno-demokratycznych oznaczać będzie porzucenie atawistycznej rywalizacji i solidarności wspólnotowej, jednak na przełomie lat 60. i 70. grupy secesjonistów, oraz formy etnicznego nacjonalizmu pojawiły się niespodziewanie w wielu częściach Europy Zachodniej. Najbardziej widoczne było to w Szkocji i Walii w Wielkiej Brytanii, Katalonii i Kraju Basków w Hiszpanii, na Korsyce we Francji, we Flandrii w Belgii. W rezultacie ich aktywności pojawiły się żądania decentralizacji politycznej, a w niektórych przypadkach doszło do przyspieszenia wprowadzania ważnych zmian konstytucyjnych. We Włoszech proces ten rozpoczął się dopiero w latach 90. wraz z powstaniem Ligi Północnej w Lombardii 5 .

Polityka etniczna jest sposobem politycznego wyzwolenia, a jej wrogami są strukturalna nierówność i zakorzeniona dyskryminacja. Wskrzeszona lojalność regionalna często wyrasta z systemu „wewnętrznego kolonializmu”, w którym peryferyjne obszary geograficzne są wykorzystywane przez „rdzeń” czy też „,entrum”. Nastroje nacjonalistyczne w Szkocji i Walii spowodowane są zatem częściowo ich ekonomicznym podporządkowaniem Anglii, a zwłaszcza Anglii południowo-wschodniej. Znajduje to swój wyraz w tradycyjnym uzależnieniu tych regionów od przemysłu ciężkiego, w wysokim poziomie bezrobocia i niższych wynagrodzeniach. Podobna

${ }^{5}$ Etniczność jest rozumiana, jako forma tożsamości kulturowej, ale taka, która działa na głębokim poziomie emocji. Kultura „etniczna” obejmuje wartości, tradycje i praktyki, ale co istotne, daje także danej grupie wspólną tożsamość i poczucie odrębności, zazwyczaj skupiając się na wspólnych korzeniach i pochodzeniu. Niektórzy uważają, że narody są po prostu dużymi grupami etnicznymi, inni podkreślają, że, podczas gdy grupy etniczne są zawsze grupami kulturowymi i ekskluzywnymi (nie można do nich „przystąpić”), narody są bardziej inkluzywne i, co ważniejsze, definiowane w kategoriach politycznych. 
sytuacja dotyczy takich obszarów jak Bretania we Francji oraz Katalonia i Kraj Basków w Hiszpanii. Na tych terenach nacjonalizm o zabarwieniu etnicznym zwykle ma charakter lewicowy, zazwyczaj głoszą go partie i ruchy, które przyjmują szeroko pojętą filozofię socjalistyczną. Natomiast, gdy poziom lojalności regionalnej wzrasta na obszarach centralnych, które muszą zmierzyć się z rosnącym znaczeniem obszarów peryferyjnych, polityka etniczna często przybiera bardziej prawicowy charakter. Taki przypadek miał miejsce chociażby we Flandrii w Belgii, kiedy rozwój gospodarczy w zdominowanej przez ludność francuskojęzyczną Walonii spowodował wzrost poparcia dla ruchów neofaszystowskich. W latach 90. głoszący otwarcie rasistowskie hasła Blok Flamandzki, nawołujący do masowej deportacji imigrantów, odnotował wzrost poparcia wyborczego na obszarach przemysłowych, zwłaszcza w Antwerpii. Podobnie filozofia wolnorynkowa Ligi Północnej w Lombardii we Włoszech częściowo odzwierciedla pragnienie rozwiniętej gospodarczo północy Włoch, by odłączyć się od rolniczego i słabiej rozwiniętego południa.

Jednak nierówności strukturalne i wewnętrzny kolonializm nie tłumaczą w całości powstania polityki etnicznej i regionalnej. Dlaczego na przykład tożsamość etniczna i regionalna stały się tak ważne pod koniec XX wieku, choć niesprawiedliwość, której się przeciwstawiają, trwa od pokoleń, a nawet od wieków? Odpowiedzią na to pytanie możne być zjawisko postmodernizmu. Nacjonalizm powstał w celu zapewnienia kulturowej spójności w nowoczesnych, uprzemysłowionych społeczeństwach, świadomość etniczna może pełnić funkcję niezbędnej siły integrującej w powstających społeczeństwach postmodernistycznych. Problem z postmodernizmem polega na tym, że promuje on różnorodność i osłabia tradycyjne tożsamości społeczne. Na przykład większa ruchliwość społeczna oraz rozprzestrzenienie się indywidualizmu rynkowego podważyły zarówno solidarność klasową, jak i utrwalone więzi polityczne. W tym samym czasie zdolność narodu do tworzenia silnej i stabilnej tożsamości społecznej została osłabiona przez globalizację w jej ekonomicznych, kulturowych i politycznych przejawach. W takich okolicznościach etniczność może zastąpić narodowość, jako podstawowe źródło integracji społecznej. Zaletą tego może być fakt, że podczas gdy narody skupiają się wokół „obywatelskiej” lojalności i więzi, grupy etniczne i regionalne są w stanie stworzyć głębsze poczucie „organicznej” tożsamości.

Upadek komunizmu w Europie wywołał widmo walki etnicznej i konfliktów regionalnych. W byłym ZSRR, Czechosłowacji i Jugosławii na przykład doprowadziło to do upadku państwa i powstania szeregu nowych państw narodowych. Przyczyny takiego rozwoju wydarzeń były złożone. Po pierwsze, mimo iż reżimy komunistyczne próbowały rozwiązać kwestię narodowościową za pomocą stworzenia homo sovieticus, rzeczywistość pokazała, że tym sposobem jedynie wzmocniły lojalność etniczną i narodową przez zepchnięcie ich do podziemia. Po drugie, nacjonalizm o zabarwieniu etnicznym lub religijnym bez wątpienia był formą antykomunizmu lub antysowietyzmu. Po trzecie, niestabilność polityczna i niepewność ekonomiczna, której katalizatorem był upadek komunizmu, była doskonałym gruntem dla rozwoju takiej formy polityki, która oferowała organiczny charakter zbiorowej tożsamości. Niemniej nowopowstałe państwa same stały się areną głębokiej rywalizacji etnicznej i napięć. Pokazała to walka Czeczenów w Rosji (Matysiak, 2007, s. 159-164) oraz fragmentacja Bośni, będącej wcześniej republiką w obrębie Jugosławii, na „czyste etnicznie” obszary zamieszkane przez Mu- 
zułmanów, Serbów i Chorwatów. Potwierdza to stan obecny „państwowości” w Bośni i Hercegowinie, czy Kosowie (Heywood, 2006, s. 214-217).

\section{Kwestie etniczno-narodowe}

Immanentną cechą narodu - państwa jest dążenie do zapewnienia koherencji granic etnicznych (kulturowych, narodowych) oraz politycznych. Chodzi o objęcie strukturami państwowo-terytorialnymi wszystkich rdzennych i etnicznych elementów kulturowych, czemu odpowiada istniejąca na zewnątrz odwrotna tendencja - dążenie pozostałych poza państwem tożsamości etniczno-kulturowych i terytorialnych do scalenia z macierzą ${ }^{6}$. Obie te tendencje stanowią jedną z podstaw nacjonalizmu. Ich uzupełnieniem jest absolutyzowanie interesu własnego narodu, tworzenie doktryn, ideologii i wartości podkreślających jego wyjątkowość, a także ruchów politycznych i partii, które stają się realizatorami tych idei. Inspiracje narodowe i kulturowe grup etnicznych tworzących naród, zwłaszcza dziedzictwo kulturowe, stają się siłą spajającą państwo i siłą napędową jego polityki, zarówno wewnętrznej, jak i zagranicznej. Można powiedzieć, że następuje pełne zespolenie i nałożenie się interesów narodowych i państwowych.

Doszło do tego jednak dopiero w fazie wchodzenia państw i narodów w epokę industrialną, która z jednej strony ze względu na nowe możliwości techniczne (mobilność ludzi, rozwój kontaktów, wzrostu zamożności, ubezpieczenia społeczne), tworzyła warunki egalitaryzmu i liberalnego rozwoju, sprzyjającego różnorodności kulturowej, z drugiej zaś nie przekładała tego podejścia na stosunki międzynarodowe, gdyż silniej artykułowane interesy państwa i narodu rodziły nacjonalizm i uwypuklały sprzeczności w stosunkach między państwami. Skutkiem były narastające spory i konflikty prowadzące do użycia siły, w których coraz ważniejszą rolę odgrywały tendencje do dominacji, osłabiania i podporządkowania innych państw.

Źródła tej asymetrii dostrzega się w historycznie ukształtowanych relacjach ideologicznych, w ramach, których narody dążą do współpracy, czynnik państwowy zaś (państwo), racja stanu, spycha je na pozycje rywalizacji ideologicznej, politycznej, gospodarczej. Jest to prymat interesów kulturowo-narodowych, wspólnotowych nad polityczno-państwowymi. W praktyce rozwój stosunków międzynarodowych dokonywał się dwutorowo. Dominował, od kiedy sformułowano pojęcie staat raison, nurt rywalizacji państw, przedkładających interesy polityczne (ideologiczne, gospodarcze, militarne) państwa, które - paradoksalnie - nacjonalizm uwypuklał, nad interesami wspólnotowymi, integrującymi narody.

Nacjonalizm, cecha właściwa narodom tworzącym państwo, odegrał ogromną rolę w rozwoju stosunków międzynarodowych i nadal jest jedną z sił napędowych tych stosunków. Szczególny, bo destrukcyjny wpływ, wywarł nacjonalizm na politykę międzynarodową okresu międzywojennego, gdy - powiązany z ideologią faszystowską i polityką nienawiści rasowej prowadzonej przez Rzeszę Niemiecką po dojściu do władzy partii nazistowskiej - doprowadził do wybuchu II wojny światowej i bezprecedensowych w skali ofiar i zniszczeń (Piwnicki, 2007, s. 220-236).

${ }^{6}$ Tendencje te obecnie najsilniej chyba występują w narodzie węgierskim i są konsekwencją okrojenia tzw. Wielkich Węgier w wyniku Traktatu wersalskiego (traktatu w Trianon). Na skutek jego postanowień, około $70 \%$ dawnego terytorium i ludności pozostało poza państwem węgierskim. 
Zajmujący się problematyką nacjonalizmu E. Gellner podkreśla sprzężenie tego zjawiska z procesami kolonializmu i imperializmu, wiążąc te procesy z ekspansją europejską, jako skutkiem najwcześniejszego wejścia Europy (Zachodniej) w fazę społeczeństwa industrialnego. Zdaniem Gellnera, dzięki temu Europa podbiła i zdominowała inne kontynenty lub znaczne ich połacie, zarówno w aspekcie politycznym i militarnym, jak i kulturowym (Gellner, 1991, s. 56). Jest to niewątpliwie uproszczenie, choć niepozbawione historycznych podstaw.

Generalnie można jednak powiedzieć, że nacjonalizm był podstawą stosunków międzynarodowych, które opierały się na relacjach dominacji i podporządkowania, rywalizacji i zdobywania korzystnych, mocarstwowych pozycji jednych państw kosztem innych. Dwie wojny światowe i wielka ilość wojen kolonialnych, a także wojen o zasięgu lokalnym, w których kwestie dominacji, stosunków religijno-etnicznych, rasowych, ideologicznych lub językowych odgrywały obok nacjonalizmu zasadniczą rolę, to cena, którą świat musiał zapłacić za tego typu dewiacje. Niejednokrotnie tendencje nacjonalistyczne okazały się tak silne, że przykryte swoistą pokrywą ustrojów totalitarnych, też zresztą mających wiele wspólnego z nacjonalizmem, potrafiły przetrwać trwający dziesiątki lat okres swoistej hibernacji, by w sprzyjających warunkach (np. po rozpadzie komunizmu) się odrodzić.

Tragiczne, szczególnie dla Europy, skutki światowych kataklizmów wojennych, zrodziły w zachodniej części kontynentu, w oparciu o system demokratyczny i wolność gospodarczą, silną tendencję do zapoczątkowania procesów integracyjnych, których głównym celem, obok integracji gospodarczej, było wyeliminowanie nacjonalizmu $\mathrm{w}$ stosunkach europejskich. Była to jedna z głównych przesłanek budowania Wspólnot Europejskich. Upadek komunizmu i struktur z nim związanych, usuwanie barier hamujących rozwój kontaktów i wymiany gospodarczej, procesy deregulacji, a także integracji, wyniosły współpracę międzynarodową na nowy poziom: instytucjonalizacji (rozwój organizacji międzynarodowych) i współzależności oraz przyspieszenie procesu globalizacji. Nastąpił rozwój struktur ponadnarodowych i niepaństwowych. Państwa w przyspieszonym tempie zaczęły tracić monopol na rozwój stosunków międzynarodowych, a nacjonalizm stracił - mimo zdarzających się tu i ówdzie przejawów - naturalne podstawy swego rozwoju.

Ważną płaszczyzną stosunków międzykulturowych są relacje etniczne, zwłaszcza te, które wyrastają na gruncie egoistycznych dążeń ich członków do dominacji językowej, religijnej, ideologicznej czy kulturowej. Tak charakterystyczne dla faz prenarodowych, przedpaństwowych, w dalszych etapach rozwoju, obejmujących już fazę państwowości, przekształcały się w ideologię odrębności etnicznej bądź nacjonalizmu. Jedną z wersji światopoglądu afirmującego odrębność etniczną jest etnocentryzm, czyli taki rodzaj tożsamości kulturowej, która wyraża się zarówno w postawach członków grupy, jak i w zbiorowej formie świadomości koncentrującej się na interesach własnej grupy oraz uznawanych przez nią wartościach. Prowadzi to do utrwalenia struktur międzykulturowych, opartych na izolacji, niechęci, wrogości i konflikcie, sprzyjających postawom separatystycznym, segregacji i wzajemnemu wykluczaniu się grup.

Etnocentryzm ma zarówno pozytywne, jak i negatywne strony. Niewątpliwie dodatnio wartościuje własną grupę, budzi dumę z przynależności etnicznej, z własnej tożsamości, ale i z zakładanej wyższości kulturowej, przeradzającej się niekiedy w etnofobię, 
czyli wrogość wobec innych grup kulturowych. W skrajnych przypadkach etnofobia przybiera formę stałego antagonizmu, trwającego dziesiątki i więcej lat. Przykładem są stosunki etniczne na Bałkanach, konflikt izraelsko-palestyński czy turecko-armeński. Etnocentryzm stanowi potencjalne źródło konfliktu kulturowego, wykazuje tendencję do przeradzania się w otwarte konflikty etniczne, prowadzące do przemocy i użycia siły, czystek etnicznych, a nawet do masowych morderstw i aktów ludobójstwa. Konflikty te mogą mieć charakter wewnętrzny, czyli występować na obszarze jednego państwa, ale ich dynamika rozwojowa jest na tyle nieobliczalna, że mogą się przekształcić w konflikt międzynarodowy (tzw. umiędzynarodowiony konflikt wewnętrzny), np. poprzez interwencję humanitarną, pomoc grup etnicznych z ościennych krajów itp. Niektóre grupy etniczne, mimo swej liczebności, bogatych tradycji i historii, a także odrębności językowej, nie zdołały utworzyć własnego państwa (np. Kurdowie) (Grgies, 1995). Mimo to dążenie do stworzenia własnej państwowości lub posiadania szerokiej autonomii jest trwałe w ich świadomości (Czaja, 2008, s. 134-136).

\section{Dewolucja - perspektywy}

Dewolucja $^{7}$ w jej kwestii ustawodawczej, w największym stopniu pozwala na decentralizację w państwie unitarnym, zbliżając się tym samym prawie do przekształcenia w państwo federalne. Zgromadzenia powstałe na skutek dewolucji zazwyczaj tworzono w odpowiedzi na wzrost odśrodkowych napięć w obrębie państwa, próbując pogodzić rosnące napięcia o charakterze separatystycznym. Zgromadzenia powstałe na skutek dewolucji nie posiadają zagwarantowanych kompetencji jednak trudno je osłabić czy zlikwidować, ponieważ uzyskały własną tożsamość polityczną oraz demokratyczną legitymację. Wyjątek stanowi Zgromadzenie Północnoirlandzkie (Stormont), które zawieszono w 1972 roku i zastąpiono przez bezpośrednie rządy parlamentu brytyjskiego, ale nastąpiło to dopiero wtedy, gdy stało się jasne, że dominacja protestanckich ugrupowań unionistów uniemożliwia mu powstrzymanie rosnącej fali przemocy społecznej w Irlandii Północnej, co groziło przekształceniem się w wojnę domową.

Jedną z najstarszych tradycji władzy poddanej dewolucji posiada Hiszpania. Mimo, iż jest państwem unitarnym od lat 70. XVI wieku, dzieli się na pięćdziesiąt prowincji, z których każda posiada pewną dozę autonomii regionalnej. Jednym z elementów przejścia do rządów demokratycznych po śmierci generała Franco w 1975 roku było poszerzenie zakresu procesu dewolucji w 1979 roku poprzez utworzenie siedemnastu wspólnot autonomicznych. Ten nowy szczebel władzy regionalnej opiera się na pochodzących z wyborów zgromadzeniach, wyposażonych w szerokie uprawnienia w zakresie polityki lokalnej. Mimo iż reforma ta miała na celu wyjście naprzeciw wysuwanym od dawna żądaniom autonomii katalońskiej, wywołała jedynie nową falę aktów terroru w Kraju Basków, dokonywanych przez ruch separatystyczny ETA. Francuski rząd rów-

${ }^{7}$ Dewolucja jest przekazaniem władzy przez władzę centralną podległym jej instytucjom regionalnym. Organy powstałe w wyniku dewolucji, zatem tworzą pośredni szczebel pomiędzy władzą centralną a lokalną. Dewolucja różni się jednak od federalizmu tym, że mimo, iż terytorialna jurysdykcja może być podobna, organy powstałe na skutek dewolucji nie są suwerenne - ich obowiązki i kompetencje pochodzą od władzy centralnej i są przez nią określane. 
nież traktował dewolucję, jako odpowiedź na trwałość tożsamości regionalnych oraz, przynajmniej w przypadku Bretanii na wzrost nacjonalizmu etnicznego ${ }^{8}$. Strategią „regionalizmu funkcjonalnego" było stworzenie w 1972 roku dwudziestu dwóch organów władzy regionalnej w celu wzmocnienia koordynacji administracji w zakresie inwestycji lokalnych oraz decyzji dotyczących planowania. Brakowało im jednak demokratycznych podstaw, a ich kompetencje były ograniczone. W 1982 roku przekształcono je we w pełni rozwinięte władze regionalne, posiadające pochodzącą z wyborów bezpośrednich radę. Próbą zahamowania separatyzmu oraz rosnącej fali terroryzmu było nadanie Korsyce specjalnego statusu, który w praktyce uczynił z niej autonomiczną wyspę. Tendencję do decentralizacji w Europie wzmacniał jednak również rozwój wydarzeń w obrębie UE, a zwłaszcza powstanie w końcu lat 80. idei „Europy regionów”. Regionalny i prowincjonalny szczebel władzy w odpowiedzi na korzyści płynące z bezpośredniej dystrybucji pomocy z Europejskiego funduszu Rozwoju Regionalnego, dążyły do posiadania bezpośredniej reprezentacji w Brukseli oraz wzmocnienia swojej roli w planowaniu gospodarczym oraz rozwoju infrastruktury.

W Wielkiej Brytanii, będącej tradycyjnie jednym z najbardziej scentralizowanych państw, proces dewolucji był dużo wolniejszy. Ożywienie nacjonalizmu szkockiego i walijskiego pod koniec lat 60. XX wieku postawiło na porządku dziennym problem dewolucji, a nawet doprowadziło do złożenia (w 1978 roku i ponownie w roku 1979) przez mniejszościowy rząd laburzystowski propozycji rozwiązań, które jednak zakończyły się niepowodzeniem, tak że dopiero w 1999 roku pojawiły się organy będące rezultatem dewolucji. Parlament szkocki jest największym i posiadającym największe kompetencje spośród nich. Posiada prawo do regulowania poziomu podatków (zdolność podwyższania i obniżania podatku dochodowego o trzy pensy na funcie) oraz pierwszeństwo w kompetencjach ustawodawczych w sprawach dotyczących regionu. Nadal jednak kontrolę nad sprawami konstytucyjnymi, obroną, sprawami zagranicznymi, bezpieczeństwem narodowym oraz stosunkami z Unią Europejską posiada parlament brytyjski. Zgromadzenie Walijskie jest przykładem dewolucji administracyjnej, gdyż nie posiada kontroli w sferze podatków i jedynie delegowaną władzę ustawodawczą. Zgromadzenie Północnoirlandzkie powstało $\mathrm{w}$ rezultacie trwającego procesu pokojowego, jako element porozumienia z Wielkiego Piątku; posiada prawną samodzielność ustawodawczą, ale pozbawione jest kontroli nad podatkami, choć jego kompetencje wzrosną zgodnie z zasadą „poszerzania” dewolucji, jeśli podział władzy zakończy się sukcesem. Zwolennicy dewolucji twierdzą, że poprzez nadanie pewnej dozy „autonomii”, zwłaszcza Szkocji i Walii, tendencje odśrodkowe wytwarzane przez nacjonalizm separatystów osłabną, co przyczyni się do konsolidacji wielonarodowego państwa brytyjskiego. Z drugiej strony krytycy ostrzegają, że dewolucja doprowadzi do ostatecznego rozpadu Wielkiej Brytanii.

Dewolucja w Wielkiej Brytanii ma już jednak quasi-federalny charakter, wprawdzie organy szkockie, walijskie i północnoirlandzkie nie mają konstytucyjnego umocowania, to dzięki temu, że są zgromadzeniami powszechnymi powstałymi w rezultacie referendum, posiadają legitymację demokratyczną, a więc umocowanie polityczne. Ponadto, asymetryczny charakter dewolucji brytyjskiej stwarza ciągle naciski, które mogą prowadzić do zwiększania kompetencji organów regionalnych - zgromadzenia walijskie i północnoir-

${ }^{8}$ Nacjonalizm etniczny - forma nacjonalizmu, która czerpie przede wszystkim z poczucia etnicznej odrębności i pragnienia jej zachowania. 
landzkie będą dążyć do uzyskania takich kompetencji, jakie posiada parlament szkocki, a parlament szkocki będzie z kolei chciał zachować swój wyższy status. Co najważniejsze, $\mathrm{w}$ takim stopniu, w jakim nowe legislatury stanowią centrum lojalności politycznej i patriotyzmu, dewolucja może powodować dalsze osłabianie i tak słabego poczucia „brytyjskości", które leży u podstaw terytorialnej integralności Wielkiej Brytanii, a naciski w stronę federalizmu mogą przyspieszyć upadek państwa (Heywood, 2006, s. 212-213).

\section{Zakończenie}

Środowiska intelektualne i część naukowców pokłada nadzieję w sile socjalizacji i kultury politycznej państwa demokratycznego, które może zaoferować społeczeństwom swoje atrybuty: drogę do godnego, sprawiedliwego cywilizowanego porządku prawnego zabezpieczającego również kwestie ekonomiczne, a przede wszystkim pokój społeczny i stabilizację życia społecznego. Może się również okazać, że to nie wystarczy. Sama demokracja i tolerancja niekoniecznie muszą się okazać wystarczające dla relacji międzykulturowych. W warunkach coraz bardziej zróżnicowanej etnicznie i religijnie struktury społecznej dobrym rozwiązaniem wydaje się zwiększenie roli społeczeństwa obywatelskiego i partycypacji różnych grup kulturowych w procesach decyzyjnych, przynajmniej na szczeblu lokalnym. Państwa powinny też bardzo precyzyjnie określać granice własnej tolerancji. Najlepszym tego instrumentem jest prawo, którego normy można negocjować także ze wspólnotami etnicznymi, ale które jest tworzone dla wszystkich i winno być przestrzegane przez wszystkich, niezależnie od tradycji kulturowych, solidarności etnicznej czy nakazów wynikających z przynależności religijnej. Mniejszości etniczne i religijne powinny się czuć w krajach przebywania bezpieczne, bez kompleksu dyskryminacji, ale też mieć świadomość, że parasol socjalny państwa ma określoną pojemność i me można go w imię spokoju społecznego rozciągać w nieskończoność. W przeciwnym wypadku mogą pogłębiać funkcjonujące negatywne stereotypy i wyzwalać nieobecne wcześniej postawy nacjonalistyczne w większości społeczeństwa. Większości, grupy dominujące są nie mniej etniczne niż mniejszości. Muszą też pamiętać, że miejsce pobytu jest niemal zawsze kwestią ich wyboru.

Stabilność porządku globalnego zagwarantować może wyłącznie rygorystyczne przestrzeganie prawa zarówno wewnętrznego, jak i międzynarodowego. W warstwie politycznej w stosunkach międzynarodowych korzystna dla wszystkich byłaby większa demokracja i rozłożenie odpowiedzialności na znaczniejszą liczbę podmiotów. Natomiast w stosunkach wewnętrznych nie można dopuszczać do sytuacji, w której poprawność polityczna przeobraża się we własną karykaturę. Nie służy to ani państwu, ani stosunkom międzynarodowym, w pewnym momencie może, bowiem stracić charakter wyłącznie wewnętrzny i wylać się na zewnątrz, zakłócając porządek międzynarodowy (Michałowska, 2010, s. 60).

\section{Bibliografia}

Chwalba A. (2011), Historia Powszechna 1981-2011, Warszawa.

Czaja J. (2008), Kulturowe czynniki bezpieczeństwa, Kraków.

Dobraczyński M., Stefanowicz J. (1979), Tożsamość Europy, Warszawa. 
Gellner E. (1991), Narody i nacjonalizm, przeł. T. Hołówka, Warszawa.

Grgies A. (1995), Sprawa kurdyjska w XX w., cz. I, II i III, Instytut Spraw Międzynarodowych UW, Warszawa.

Grott B. (1999), Nacjonalizm chrześcijański. Narodowo-katolicka formacja ideowa w II Rzeczypospolitej na tle porównawczym, Krzesłowice.

Heywood A. (2006), Politologia, Warszawa.

Kuczyński M. (2001), Krwawiaca Europa konflikty zbrojne i punkty zapalne w latach 1990-2000. Tło historyczne $i$ stan obecny, Warszawa.

Jackson R. (2011), Suwerenność, Warszawa.

Matusiak E. (2007), Narody Pólnocnego Kaukazu. Historia - kultura - konflikty 1985-1991, Toruń.

Michałowska G. (2010), Dyferencjacja cywilizacyjno-kulturowa świata a jedność porządku międzynarodowego, w: Świat wobec współczesnych wyzwań i zagrożeń, red. J. Symonides, Warszawa.

Piwnicki G. (2007), Wpływ traumatycznych doświadczeń Polaków i Niemców z okresu II wojny światowej na normalizację stosunków bilateralnych w jednoczacej się Europie po wstapieniu Polski do Unii Europejskiej, w: Ksztaltowanie się Nowego Ladu Międzynarodowego, red. A. Chodubski, M. Malinowski, E. Polak, P. Trawicki, Gdańsk.

Piwnicki G. (2016), Przyszłość bezpieczeństwa społecznego Unii Europejskiej wglobalnej rzeczywistości XXI wieku przez pryzmat megatrendu minimalizacji kosztów pracy i robotyzacji, „Cywilizacja i Polityka", nr 14, Toruń.

Piwnicki G. (2017), Syndrom reintegracji w stosunkach Polski z Uniq Europejska po roku 2015, „Сywilizacja i Polityka", nr 15.

Nacjonalizm kontra światowy ład. Co będzie górą?, „The Wall Street Journal” 22.01.2018, thum. Agnieszka Rostkowska.

Stasiński M., ETA się rozwiązuje, ale nie kaja, „Gazeta Wyborcza” z dn. 20.04.2018.

Tomaszewski W., http://wolność24.pl (odczyt: 15.03.2018 r.).

Waniek D. (2014), Ruch narodowy w Polsce wczoraj i dziś, ideologia, organizacja, praktyka działania, Warszawa.

\section{Separatist and disintegrating movements at the turn of the 20th and 21st century in Europe}

\section{Summary}

The existence of separatist and disintegrating movements in Europe, hot spots and armed conflicts, argues that our continent is neither peaceful nor safe place. Even if we consider it the safest place on our planet. After 1989, democracy prevailed in Europe, in 1999-2013 the Central and Eastern European countries were included into the Western defence (NATO) and economic (EU) structures, with great hopes for the future. In the second decade of the twenty-first century completely different tendencies appeared in Europe. Separatist and populist movements intensified their activity in almost all European countries (Rostowska 2018).

The article raises the following research questions:

1. What is the source of separatist-populist movements?

2. What is the basis of the revival of nationalism in European countries?

3 . Why is the policy of autonomous autonomy not working?

4. What can be the result of the ethnic disintegration of other countries in Europe?

The article uses the comparative method and system analysis. Analyzing the problem, the author came to the following conclusions: 
1. There are problems in Europe that have led and may lead to wars.

2. No state can feel safe even if it is stable and democratic.

3. Extremist political parties and movements may destabilize the continent.

4. The only antidote in calming conflicts and eliminating separatist situations is a well-established and stable democracy.

5. European policy (EU) should be unambiguous and stable in this matter.

Key words: separatist movements, ethnic policy, identity, disintegration 